\title{
Kebijakan Kepala Sekolah untuk Meningkatkan Mutu Pendidikan Sekolah Dasar
}

\author{
Ilham \\ Program Studi Pendidikan Guru Sekolah Dasar, STKIP Yapis Dompu \\ E-mail: ilhamtarbiyah@gmail.com
}

Article History: Received: 2021-05-12 || Revised: 2021-07-17 || Published: 2021-08-15
Sejarah Artikel : Diterima: 2021-05-12 || Direvisi: 2021-07-17 || Dipublikasi: 2021-08-15

\begin{abstract}
A school principal is required to understand what role he must carry out, whether as an educator, manager, administrator, supervisor, leader, innovator, or motivator. By knowing and properly carrying out the leadership role, the principal will be able to lead the institution he leads properly. In this study using descriptive qualitative methods with analytical techniques in this study is descriptive analysis, namely describing the policies carried out by school principals in order to improve the quality of education, then analyzing them with evidence of the validity of the existing data, In educational institutions, the principal as someone who has been given the authority to lead an educational institution and must be fully responsible for the implementation of school education under the leader. The progress of an educational institution is much influenced by the principal, including the problem of improving the quality of education. Efforts to improve the quality of education in schools include educational programs in teacher schools by increasing teacher discipline, increasing knowledge, and fostering teacher performance training in addition to efforts to improve the quality of students by providing guidance, as well as the availability of infrastructure to support the learning process and and collaboration with parents.
\end{abstract}

Keywords: Policy, Principal, Quality of Education

\begin{abstract}
Abstrak
Kepala sekolah dituntut untuk memahami peran apa yang harus dijalankannya, apakah sebagai educator, manager, administrator, supervisor, leader, innovator, atau motivator. Dengan mengetahui dan menjalankan dengan benar peran kepemimpinan tersebut, maka kepala sekolah akan mampu memimpin lembaga yang dipimpinnya dengan baik. Dalam penelitian ini menggunakan jenis metode kualitatif deskriptif dengan teknik analisis dalam penelitian ini adalah analisis deskriptif yaitu mendeskripsikan kebijakan yang dilakukan kepala sekolah dalam rangka meningkatkan mutu pendidikan, kemudian menganalisisnya dengan bukti kebenaran data yang ada, Dalam lembaga pendidikan, Kepala sekolah sebagai seseorang yang telah diberi wewenang untuk memimpin suatu lembaga pendidikan dan harus bertanggung jawab secara penuh terhadap penyelenggaraan pendidikan sekolah yang berada di bawah pemimpinnya. Maju mundurnya suatu lembaga pendidikan itu banyak di pengaruhi oleh kepala sekolah, termasuk juga masalah peningkatan mutu pendidikan. Upaya meningkatkan mutu pendidikan di sekolah adanya program-program pendidikan di sekolah guru dengan menigkatkan kedisiplinan guru, meningkatkan pengetahuan, dan Pembinaan pelatihan kinerja guru di samping itu juga upaya meningkatkan mutu adanya siswa dengan memberikan bimbingan, serta tersedianya sarana prasarana guna mendukung proses pembelajaran dan dan adanya kerja sama dengan wali murid
\end{abstract}

Kata kunci: Kebijakan, Kepala Sekolah, Mutu Pendidikan

\section{PENDAHULUAN}

Pendidikan merupakan suatu hal yang sangat penting dalam menentukan perkembangan dan perwujudan diri individu, dan bagi kehidupan suatu bangsa. Menyadari akan pentingnya peranan pendidikan sebagai pendorong kemajuan suatu bangsa, maka pemerintah senantiasa berupaya untuk mengadakan pembaharuanpembaharuan bidang pendidikan terutama yang berkaitan dengan tenaga pendidikan, pembiayaan, sistem, kurikulum, dan lain sebagainya adalah peningkatan mutu pendidikan, sehingga Undang-undang nomor 20 tahun 2003 tentang Sistem Pendidikan Nasional pasal 4 ayat 6 juga menegaskan bahwa: "Pendidikan diselenggarakan dengan memberdayakan semua komponen masyarakat melalui peran serta dalam penyelenggaraan dan 
pengendalian mutu layanan pendidikan", Sebagaimana tersebut dalam undang undang No 20 Tahun 2003 tentang sistem pendidikan Nasional menegaskan bahwa pendidikan nasional berfungsi mengembangkan kemampuan dan membentuk watak serta peradaban bangsa yang bermatabat dalam rangkah mencerdaskan kehidupan bangsa, bertujuan untuk berkembangnya potensi peserta didik agar menjadi beriman dan bertakwa kepada tuhan yang maha esa, berakhlak mulia, sehat, berilmu, cakap.kratif mandir, dan menjadi warga negara yang demokratis serta bertanggung jawab.

Maka dengan pendidikan itu perubahan akan nampak dalam proses perubahan pikiran manusia, dari tidak mengerti menjadi mengerti, dari tidak mengetahui menjadi mengetahui karena pendidikan adalah suatu hal yang mutlak yang harus dipenuhi dalam upaya untuk meningkatkan taraf hidup manusia, agama, dan khususnya bangsa indonesia agar tidak sampai tertinggal dengan bangsa lain, dan dalam mengelola pendidikan khususnya di suatu sekolah merupakan tugas kepala sekolah agar mutu pendidikan di sekolah berkualitas dengan meren-canakan program, dimulai dari merencana-kan kebutuhan SDM yang akan menjalan-kan tugas, merencanakan kebijakan berupa program kepala sekolah dan kurikulum yang akan dijalankan di sekolah, Dalam perencanaan ini kepala sekolah selalu melibatkan guru, PKS dan komite sekolah. Peran kepala sekolah dalam mengorganisasikan program yaitu membuat struktur organisasi sekolah yang melibat-kan orang tua melalui komite sekolah, melengkapi sarana yang dibutuhkan oleh sekolah, pembagian tugas seperti adanya PKS dan TU sesuai sesuai kemampuan guru baik di tingkat kelas maupun keterampilan yang mereka miliki.

Kepala sekolah merupakan kunci keberhasilan dari sebuah sekolah atau lembaga, karena keberhasilan pencapaian tujuan dan kualitas sekolah sangat dipengaruhi oleh kepemimpinan kepala sekolah. Kepemimpinan kepala sekolah tidak terlepas dari peran dan kebijakan kepala sekolah yang bertujuan untuk meningkatkan mutu pendidikan, Sekolah atau lembaga pendidikan tidak hanya negeri, melainkan ada pondok pesantren yang pendidikannya lebih mengutamakan keagamaan Islam tetapi tetap menggunakan kurikulum terpadu layaknya sekolah formal lain. Mutu pendidikan di sekolah negeri maupun swasta dipengaruhi oleh peran kepala sekolahnya dimana kepala sekolah harus dapat berperan sebagai manajer maupun pemimpin. Lembaga yang kualitas atau mutunya baik pasti mempunyai kepemimpinan kepala sekolah yang baik didalamnya, sehingga peran kepala sekolah menentukan keberhasilan atau tidaknya mutu pendidikan di sekolah, Dalam dunia pendidikan di erah globalisasi masalah yang sangat serius dalam bidang pendidikan di negara kita adalah rendahnya mutu pendidikan di berbagai jenis dan jenjang pendidikan. Berbagai kalangan masyarakat, termasuk ahli pendidikan, bahwa masalah mutu pendidikan sebuah proses pendidikan sebagai salah satu faktor yang dapat menghambat penyediaan sumber daya manusia sebagai modal utama pembangunan bangsa dalam berbagai bidang. khususnya dalam mutu pendidikan pada jenjang pendidikan dasar dan menengah masih rendah.

Oleh karena itu, sekolah di tuntut dalam meningkatkan mutu pendidikan adalah dengan terwujud kebijakan kepala sekolah dalam memimpin dan mengatur kegiatan di sekolah sehingga dapat meningkatkan kinerja guru, pada akhirnya meningkatkan prestasi belajar peserta didik dan penyedian sumber daya manusia dan meningkatkan kinerja guru dengan mengatur kegiatan kegiatan di sekolah yang di buat oleh kepala sekolah, Dalam meningkatkan mutu pendidikan adalah dengan melihat berbagai faktor faktor yaitu. Menurut Fattah dalam buku Engkoswara dan Aan Komariah ada tiga faktor untuk meningkatkan mutu pendidikan yaitu: (1) kecukupan sumber sumber pendidikan dalam arti mutu tenaga kependidikan, biaya, sarana belajar, (2) mutu proses belajar yang mendorong siswa belajar efektif,dan (3) mutu pengeluaran dalam bentuk pengetahuan, sikap, keterampilan dan nilai-nilai, Dengan demikian, mutu pendidikan di sekolah akan berkembang dan memiliki kontribusi yang besar terhadap kemajuan suatu bangsa sehingga tidak dapat diabaikan eksistensinya sebagai wadah untuk mendidik dan mengajarkan ilmu pengetahuan dengan terpenuhnya tenaga kependidikan, biaya sarana belajar, sehingga mendrong siswa belajar efektif dalam bentuk pengetahuan, sikap, keterampilan dan nilai nilai.

Dalam konteks pendidikan, mutu mencakup input, proses, dan output pendidikan input pendidikan adalah segala sesuatu yang harus tersedia karena dibutuhkan untuk berlangsungnya proses yang inputnya yaitu struktur organisasi sekolah peraturan perundang undangan, visi misi tujuan dan sasaran yang ingin di capai. Oleh karena itu tinggi rendanya mutu input dapat diukur dari tingkat kesiapan input, Namun demikian, indikator mutu pendidikan menunjukkan peningkatan yang 
berarti bahwa mutu pendidikan adalah kemampuan sistem pendidikan yang diarahkan secara efektif untuk meningkatkan nilai tambah faktor input agar menghasilkan out put yang setinggitingginya, Pendidikan yang bermutu bukan hanya dilihat dari kualitas lulusannya tetapi juga mencakup bagaimana lembaga pendidikan mampu memenuhi kebutuhan pelanggan sesuai dengan standar mutu yang berlaku. Pelanggan dalam hal ini adalah pelanggan internal (tenaga kependidikan) serta pelanggan eksternal (peserta didik, orang tua, masyarakat dan pemakai lulusan).

Dengan begitu bahwa mutu pendidikan terkait dengan tuntunan dan kebutuhan masyarakat. Dimana kebutuhan masyarakat dan perubahan yang terjadi bergerak dinamis seiring dengan perkembangan zaman, sehingga pendidikan juga harus bisa menyeimbangi perubahan yang terjadi secara cepat, dan bisa menghasilkan lulusan yang sesuai dengan kebutuhan masyarakat. Pendidikan memerlukan pemetaan dan kebijakan yang profesional yaitu oleh kepala sekolah. Hal itu diperlukan personal yang mampu dan tangguh. Proses dikatakan bermutu tinggi apabila pengkoordinasian penyerasian serta pemanduan input sekolah (guru, siswa ,kurikulum sarana dan prasarana) sehingga pembelajaran yang menyenangkan akan mampu meningkatkan mutu pendidikan sekolah.

Tujuan utama pendidikan adalah terwujudnya tujuan pendidikan nasional yaitu mencerdaskan kehidupan bangsa bagaimana peserta didik menjadi harapan lulusan terbaik jika guru nya kurang kesadaran dan kepedulian dan rasa tanggung jawab. Disini kepala sekolah sebagai pemimpin membuat kebijakan yang tepat. Kepala Sekolah sebagai tulang punggung mutu pendidikan dituntut untuk bertindak sebagai pembangkit semangat, mendorong, merintis dan memantapkan serta sekaligus sebagai administrator. Dengan perkataan lain bahwa kepala sekolah adalah pengambil kebijakan, penentu arah tujuan sekolah, dan menjadi salah satu penggerak pelaksanaan manajemen pendidikan yang berkualitas, Jadi berkualitas atau tidaknya suatu mutu di sekolah akan tampak pada kebijakan kepala sekolah dalam meningkatkan mutu pendidikan sekolah. Pengawasan yang benar dan objektif menjadi kunci berkualitasnya program dan kegiatan sekolah.

\section{METODE PENELITIAN}

Jenis penelitian yang digunakan dalam penelitian ini adalah kualitatif. Menurut Lexy J. Moleong, penelitian kualitatif adalah Penelitian yang bermaksud untuk memahami fenomena tentang apa yang dialami oleh subjek penelitian misalnya perilaku, persepsi, motivasi, tindakan, dll., secara holistik, dan dengan cara deskripsi dalam bentuk kata-kata dan bahasa, pada suatu konteks khusus yang alamiah dan dengan memanfaatkan berbagai metode, Dalam penelitian ini menggunankan pendekatan deskriptif (descriptive research). pendekatan deskriptif dalam penelitian yang dilakukan untuk mendeskripsi dan menginterpretasi kondisi atau hubungan yang ada, pendapat yang sedang tumbuh, proses yang sedang berlangsung, akibat yang sedang terjadi atau kecenderungan yang tengah berkembang.

\section{HASIL DAN PEMBAHASAN}

\section{A. Kebijakan Kepala Sekolah dalam Meningkatkan Mutu Pendidikan}

Untuk meningkatkan suatu sekolah yang bermutu di perlukan suatu kebijakan yang tepat dengan membuat suatu program program sesuai dengan tujuan sekolah yaitu visi dan misi. Kebijakan kepala sekolah terdiri dari dua kata yakni kebijakan dan kepala sekolah. Sebelum kita mengetahui makna dari kebijakan kepala sekolah terlebih dahulu kita harus mengetahui makna dari kebijakan itu sendiri. Kebijakan adalah terjemahan dari kata "wisdom" yaitu suatu ketentuan dari pimpinan yang berbeda dengan aturan yang ada, yang di kenakan pada sesorang atau kelompok orang tersebut tudak dapat dan tidak mungkin memenuhi aturan yang umum tadi, dengan kata lain ia dapat pengeculian artinya wisdom atau kebijakan adalah suatu kearifan pihak yang menentukan kebijakan, dapat saja mengecualikan aturan yang baku kepada seseorang atau sekelompok orang, jika mereka tidak dapat dan tidak meungkin tadi, dengan kata lain dapat di kecualikan tetapi tidak melanggar aturan, Dalam hal ini, kebijakan berkenaan dengan gagasan pengaturan organisasi dan merupakan pola formal yang sama-sama diterima pemerintah/lembaga sehingga dengan hal itu mereka berusaha mengejar tujuannya. Menurut Gamage dan Pang dalam kebijakan adalah terdiri dari pernyataan tentang sasaran dan satu atau lebih pedoman yang laus untuk mencapai sasaran 
tersebut sehingga dapat dicapai yang dilaksanakan bersama dan memberikan kerangkah kerja bagi pelaksanaan program. Sedangkan Nichols dalam Syafaruddin kebijakan adalah suatu keputusan yang dipikirkan secara matang dan hati hati oleh pengambil keputusan puncak dan bukan kegiatan yang berulang ulang dan rutin yang terprogram atau terkait dengan aturan aturan keputusan.

Dengan demikian dari pendapat tersebut dapat di simpulkan bahwa kebijakan adalah kepandaian, kemahiran, kebijaksanaan, kearifan, rangkaian konsep dan asas yang menjadi garis besar dan dasar rencana dalam pelaksanaan suatu pekerjaan didasarkan atas suatu ketentuan dari pimpinan yang berbeda dari aturan yang ada, yang dikenakan pada seseorang karena adanya alasan yang dapat di terima seperti untuk tidak memberlakukan aturan yang berlaku karena sesuatu alasan yang kuat, Dalam rangka melaksanakan dan menetapkan suatu kebijakan pendidikan pada sebuah sekolah perlu menggunakan berbagai macam model kebijakan pendidikan sehinga tujuan yang ingin dicapai dapat terlaksana dengan baik. Adapun model pendekatan yang diperlukan dalam menetapkan suatu kebijakan pendididikan di sekolah antara lain:

1. Model Rasional murni yaitu model yang mengembangkan kebijakan secara rasional.

2. Model Ekonomi yaitu model yang mengembangkan kebijakan berdasarkan pertimbangan faktor ekonomi, model keputusan berurutan yaitu kebijakan yang mendasari pengambilan keputusan atas dasar beberapa kebijakan alternatif.

3. Model Ekperimentasl yaitu model yang menggunakan pendekatan pengambilan keijakan atas dasar perubahan sedikit demi sedikit.

4. Model memuaskan yaitu model yang mendasarkan keputusan atas dasar kebijakan alternatif yanf paling memuaskan tanpa menilai kritis alternatif lain.

5. Model Optimal yaitu model yang mendasarkan pengambilan keputusan atas dasar gabungan beberapa metode secara terpadu untuk menghasilkan kebijakan yang optimal dan dapat di terima oleh semua pihak

Dapat dsimpulkan bahwa kepala sekolah dalam membuat suatu kebijakan dengan menggunakan suatu model model kebijakan agar pengambilan keputusan untuk menghasilkan kebijakan yang optimal dan dapat di terimah oleh semua pihak berjalan dengan lancar sesuai dengan tujuan yang telah dibuatoleh kepala sekolah dengan melakukan kerjasam dengan baik antara seluruh komponen komponen sekolah, kebijakan kepala sekolah adalah suatu ketentuan kepala sekolah yang berupa rangkaian dan asas yang menjadi garis besar dan dasar rencana dalam pelaksanaan suatu pekerjaan serta cara bertindak dalam usaha mencapai tujuan yang ingin di capai di sekolah dalam mengambil suatu keputusan dalam rangkah meningkatkan mutu pendidikan, Agar kepala sekolah mampu bergerak dari pemimpin level bawah sampai level yang lebih tinggi dibutuhkan empat (4) unsur yaitu :

1. Kepala sekolah harus memiliki visi yang baik dan terbuka agar mampu menerima berbagai hal yang baru, walaupun mungkin bertentangan dengan apa yang diyakininya.

2. Unsur keberanian, kepala sekolah yang mencintai pekerjaannya akan memiliki keberanian yang tinggi dan berani mengambil resiko.

3. Kemampuan untuk bekerja dalam alam yang realistis, harus dapat membedakan mana opini dan mana yang fakta.

4. Harus memiliki kemampuan menjadi pemimpin, tidak sekedar pemimpin legalitas, adalah memiliki kepedulian dan sensitivitas yang tingi tetapi mengedapankan nilai-nilai luhur, cinta, kasih sayang dan integritas ,komitmen dalam meimimpin agar memperoleh kepercayaan.

Oleh karena itu mutu kepala sekolah sebaiknya diarahkan kepada pembentukan kepala sekolah yang efektif, namun peningkatanya sebaiknya diawali pengembangan standar kompetensi kepala sekolah yang berdasarkan tugas pokok dan fungsinya. Untuk menjamin mutu pelayanan pendidikan dan mutu manajemen pendidikan, maka pengembangan standar kompetensi kepala sekolah meliputi kompetensi kepribadian, kompetensi manajerial, kompetensi supervisi, dan kompetensi sosial. menjamin keberhasilan sekolah dalam mencapai visi dan misi yang telah ditetapkan, disamping itu, hal penting yang perlu dilakukan oleh kepala sekolah adalah membangun visi yang telah dimiliki oleh sekolah dengan mensosialisasikan, mengkomunikasikan, menghidupkan, bahkan mengembangkan visi tersebut agar mempunyai arti, bermakna bagi kehidupan sekolah dengan mengembangkan standar kompetensi kepala sekolah meliputi kompetensi kepribadian, kompetensi 
manajerial, kompetensi supervisi, dan kompetensi sosial. menjamin keberhasilan sekolah dalam mencapai visi dan misi yang telah ditetapkan.

\section{B. Peran Dan Tugas Kepala Sekolah dalam Meningkatkan Mutu Pendidikan}

Peran kepala dapat berlangsung didalam dan diluar organisasi. Karena itu salah satu peran strategis seseorang dalam organisasi lain sebagai manajer adalah kepemimpinan. Menurut Robbins dalam buku Manajemen Kepengawasan Pendidikan, Peran adalah seperangakat pola perilaku yang diharapkan berkaitan dengan tugas seseorang dalam kedudukan pada unit sosial. Sedangkan menurut Newel, Peran adalah sama dengan perilaku dalam kedudukan tertentu dan mencakup perilaku itu sendiri dan sikap serta nilai yang melekat dalam perilaku, Sebagai seorang pemimpin, fungsi dan tugas kepala sekolah sangat komleks demi terwujudnya sekolah yang berkualitas. E. Mulyasa dalam Asmani memaparkan fungsi dan tugas kepala sekolah secara terperinci yaitu:

1. Sebagai pendidik (educator) dengan meningkatkan profesionalisme tenaga kependidikan di sekolah, menciptakan iklim sekolah yang kondusif, memberikan nasehat kepada warga sekolah, memberikan dorongan kepada seluruh tenaga kependidikan, serta mengadakan akselerasi bagi siswa yang cerdas di atas rata rata.

2. Sebagai manager dalam memberdayakan tenaga kepndidikan melalui kerja sama, memberikan kesempatan kepada para tenaga kependidikan untuk meningkatkan profesinya, dan mendorong terlibatnya seluruh tenga kependidikan.

3. Sebagai administrator, dengan mengelola kurikulum, siswa, personalia, sarana prasarana, kesiapan dan keuangan.

4. Sebagai supervisor, dengan memperhatikan prinsip prinsipnya dilaksanakan secara demokrasi, berpusat pada tenaga kependidikan (guru).

5. Sebagai inovator, dengan strategi yang tepat dalam menjalin hubungan yang harmonis dengan lingkungan, mencari gagasan baru, dan memberikan teladan kepada seluruh tenaga kependidikan.

6. Sebagai motivator, Memberikan motivasi kepada tenaga kependidikan sebagai tugas dan fingsinya yang mendorong kepala sekolah dalam meningkatkan kreativitasnya terhadap pengembangan sekolah, sehingga mampu memberikan inspirasi dan motivasi kepada jajarannya dibawah agar dapat bangkit dalam memaksimalkan proses pembelajaran.

Sedangkan dalam perspektif kebijakan pendidikan nasional Depdiknas, terdapat tujuh peran utama kepala sekolah. Tujuh peran utama kepala sekolah tersebut, yaitu sebagai supervisor, edukator, manager, administrator, supervisor, leader, motovator, pencipta iklim kerja, wirausahawan, serta layanan bimbingan dan konseling, Dari sisi tenaga pendidik, kepala sekolah ditutut untuk melaksanakan kegiatan pemeliharaan dan pengembangan profesi guru. Kepala sekolah juga sebagai adminstrator dalam keuangan, sebagai supervisor dalam segala aspek pendidikan (8 standar pendidikan nasional) dan sebagai leader dalam lembaga pendidikan baik dari segi tugas maupun SDM. dan bukan hanya itu, kepala sekolah juga sebagai pencipta iklim kerja yang kondusif yang diharapkan mampu meningkatkan kualitas pembelajaran di sekolah, Kepala sekolah juga berperan sebgai wirausahawan, serta berperan dalam memberikan pelayanan bimbingan dan konseling untuk membantu personal sekolah (tenaga pendidk dan kependidikan beserta peserta didik) dalam menghadapi permasalahan dan berperan serta mencari solusi dari permasalahan yang dihadapi dengan cara membuatan aturan atau kebijakan oleh kepala sekolah.

Dapat penulis simpulkan untuk meningkatkan mutu pendidikan oleh kepala sekolah harus memberikan pelayanan dan bimbingan untuk membantu personel dalam menghadapi masalah sehingga kepala sekolah berperan untuk membuat aturan atau kebijakan dalam rangkah meningkatkan mutu lulusan dan merupakan peran dan tugas kepala sekolah untuk meningkatkan mutu pendidikan dengan memilki peran leader educator, motivator, inovator, dan adminstrator.

\section{Upaya Kepala Sekolah Dalam Meningkatkan Mutu Pendidikan Sekolah Dasar}

Untuk meningkatkan mutu lembaga pendidikan dilakukan dengan berbagai cara, yaitu dengan meningkatkan mutu tenaga akademik secara berkelanjutan, penataan program studi, peningkatan proporsi murid bidang sains dan keteknikan, pengembangan kurikulum yang fleksibel dan tekendali, peningkatan mutu penelitian dan pengabdian kepada masyarakat, pengadaan sarana prasarana dan fasilitas penunjang, peningkatan kerjasama dengan pemerintah daerah, dunia usaha, 
kalangan industridan lembaga dalam dan luar negeri, Dalam lembaga pendidikan, Kepala sekolah sebagai seseorang yang telah diberi wewenang untuk memimpin suatu lembaga pendidikan dan harus bertanggung jawab secara penuh terhadap penyelenggaraan pendidikan sekolah yang berada di bawah pemimpinnya. Maju mundurnya suatu lembaga pendidikan itu banyak di pengaruhi oleh kepala madrasah, termasuk juga masalah peningkatan mutu pendidikan. Adapun dalam peningkatan mutu pendidikan, kepala sekolah dapat melaksanakannya dengan melalui beberapa komponen, dan untuk mencapai tujuan tersebut yaitu dengan adanya komponen komponen lainnya agar dapat meningkatkan mutu pendidikan di sekolah tersebut yaitu dengan adanya:

1. Guru

Guru diharuskan memiliki kemampuan dalam merancang program pembelajaran serta mampu menata atau mengelola kelas agar peserta didik dapat belajar dan pada akhirnya dapat mencapai tingkat kedewasaan sebagai tujuan akhir proses pendidikan, Menurut Endang Komara, guru adalah pendidik profesional dengan tugas utama mendidk, membimbing, mengarahkan melatih, menilai, dan mengevaluasi peserta didik pada pendidikan anak usia dini jalur pendidikan formal, pendidikan dasar, dan pendidikan menengah, Kehadiran guru tidak akan tergantikan oleh unsur yang lain, lebih-lebih dalam masyarakat kita yang multikultural dan multidimensional, dimana peranan teknologi untuk menggantikan tugas-tugas guru sanagt minim. Begitu pentingnya peranan guru dalam keberhasilan peserta didik maka hendaknya guru mampu beradaptasi dengan berbagi perkembangan yang ada dan meningkatkan. kompetensinya sebab guru pada saat ini bukan saja sebagai pengajar tetapi juga sebagai pengelolaan proses belajar mengajar.

2. Siswa

Siswa merupakan hal yang terpenting dalam suatu pendidikan tanpa siswa suatu sekolah tidak akan maju, dalam meningkatkan mutu pendidikan siswa juga harus mendapatkan perhatian.

3. Sarana Prasarana

Untuk mencapai tujuan pendidikan yang telah ditetapkan dibutuhkan sarana yang memadai dengan sarana yang cukup maka akan memudahkan pencapaiantujuan pendidikan. Sarana dan prasarana pendidikan merupakan salah satu sumber daya yang penting dalam menunjang proses pembelajaran di sekolah, Keberhasilan program pendidikan di sekolah sangat di pengaruhi oleh kondisi saran dan prasarana pendidikan yang di miliki sekolah oleh optimalisasi dan pemanfaatannya.

4. Kerja sama dengan Wali Murid

Penyelenggaraan pendidikan akan lebih berhasil jika adanya kerja sama antara sekolah dengan orang tua murid, di mana sekolah akan memberi informasi tentang keadaan anaknya dirumah sehingga hubungan mereka itu adalah saling menunjang di dalam keberhasilan belajar siswa.

Jadi dapat penulis simpulkan upaya meningkatkan mutu pendidikan di sekolah adanya programprogram pendidikan di sekolah guru dengan menigkatkan kedisiplinan guru, meningkatkan pengetahuan, dan Pembinaan pelatihan kinerja guru di samping itu juga upaya meningkatkan mutu adanya siswa dengan memberikan bimbingan, serta tersedianya sarana prasarana guna mendukung proses pembelajaran dan dan adanya kerja sama dengan wali murid.

\section{SIMPULAN DAN SARAN}

\section{A. Simpulan}

Proses kebijakan kepala sekolah dalam rangkah meningkatkan mutu pendidikan adalah dengan melakukan perencanaan atau perumusan kebijakan yang di buat kemudian melakukan pengorganisasi yaitu bekerja sama agar kebijakan yang telah di buat dapat berjalan dan di imlementasikan serta yang terakhir adalah melakukan eveluasi yang mana program tersebut adalah visi dan misi sekolah, agar dapat meningkatkan mutu pendidikan menjadi lebih efektif dan efisien, Kebijakan dan fungsi kepala sekolah sebagai sebagai educator, manager, administrator, supervisor, leader, innovator, atau motivator sangat penting diketahui dan diterapkan oleh kepala sekolah. Sebagai pendidik, ia bisa menyelenggarakan program pembelajaran dengan menggunakan kurikulum yang difokuskan pada tiga bidang yaitu bidang keagamaan, bidang akademis, dan bidang kreatifitas. Kepala sekolah sebagai pemimpin pendidikan Islam juga harus mampu menciptakan 
lingkungan sekolah yang representatif dengan cara membiasakan kedisiplinan, menciptakan suasana kekeluargaan, meningkatkan kebersihan lingkungan sekolah dan menerapkan hadiah dan hukuman, Hal tersebut jika diterapkan akan terjadi dinamisasi lingkungan kerja dengan suasana yang nyaman, terkendali, semangat untuk mencapai tujuan. Sebagai dampaknya akan tercipta lingkungan sekolah yang kondusif untuk belajar sehingga menghasilkan lulusan yang berkualitas dan siap berkompetisi di dunia global.

\section{B. Saran}

Berdasarkan hasil penelitian yang telah dilakukan, salah satu saran yang dapat dikemukakan oleh peneliti yaitu diharapkan kepala sekolah lebih memperhatikan situasi dan kondisi yang ada di sekolah sebelum mengeluarkan setiap kebijakan yang ada di sekolahnya guna memperbaiki mutu pendidikan.

\section{DAFTAR RUJUKAN}

Ali Imron. (2008). Kebijaksanaan Pendidikan di Indonesia Proses, Produk, dan Massa Depannya. Jakarta, Bumi Aksara.

Anggota IKAPI. (2009). Himpunan Peraturan Perundang-Undangan tentang Undang Undang SISDIKNAS. Bandung: Fokusmedia.

Asrul dan Syafaruddin. (2014). Manajemen Kepengawasan Pendidikan. Bandung: Citapustaka Media.

Asru dan Syafaruddin. (2015). Kepemimpinan Pendidikan Kontemporer (Bandung: Citapustaka Media.

E. Mulyasa. (2004). Kurikulum berbasis kompetensi, konsep, karakteristik implementasi. Bandung: Rosdakarya.

Helmawati. (2014). Meningkatkan Kinerja Kepala Sekolah /Madrasah Melalui Managerial Skills. Jakarta: Reneka Cipta.

Hikmat. (2011). Manajemen Pendidikan. Bandung CV Pustaka Setia.

Inom Nasution. (2017). Profesi Kependidikan. Depok: Prenada Media Group.

Jamal Ma’mur Asmani. (2012). “Tips Menjadi Kepala Sekolah Propesinal” . Jogjakarja Diva Press.

Moleong. Lexy J. (2012). Metodologi Penelitian Kualitatif Edisi revisi. Bandung: Rosdakarya.

Muhaimin, dkk. (2009). Manajemen Pendidikan Aplikasinya dalam Penyusunan Rencana Pengembangan Sekolah/Madrsah. Jakarta: Kencana Prenada Media Group.

Ngalim Purwanto. (1984). Administrasi Pendidikan. Jakarta: Mutiara.

Nurhayati Fuad dan Matin. (2016). Manajemen Sarana dan Prasarana Pendidikan. Jakarta PT Raja Grapindo.

Pardjono dan Yogi Irfan Rosyadi. (2015). Jurnal Akuntabilitas Pendidikan : Peran Kepala Sekolag Sebagai Manajer Dalam Meningkatkan Mutu Pendidikan di SMP I Cilawu Garut. Yogyakarta : Yayasan Pendidikan Rusyani Hikmatul Rosyad, Vl. 3 No .1.

STAIN P3M . Tulungagung et.al. (2005). "Ta'alum Jurnal Pendidikan Islam”. Tulungagung, volume 28, Nomor 1.

Syafaruddin. (2008). Efektifitas Kebijakan Pendidikan :Konsep Strategi, dan Aplikasi Kebijakan Menuju Organisasi Sekolah Yang Efektif. Jakarta, PT Rineka Cipta. 
Syafi'i Asrof. (2005). Metodologi Penelitian Pendidikan. Surabaya: eLKAF.

Sylviana Murni dan Veithzal Rivai. (2010). Education Management: Analisis Teori dan Praktik.. Jakarta: Raja Grafindo Persada. 